\title{
SPATIAL MODELING OF THE THREAT OF DAMAGE TO THE PEATLAND ECOSYSTEM IN THE MAINLAND OF BENGKALIS REGENCY, RIAU PROVINCE
}

\author{
${ }^{1}$ Rizki Atthoriq Hidayat, ${ }^{2}$ Muhammad Hanif \\ ${ }^{1,2}$ Department of Geography, State University of Padang, Padang, Indonesia \\ ${ }^{1}$ rizkiatthoriq99@gmail.com,2hanif12mphy@mail.com
}

\begin{abstract}
Peatlands are the stretch of ecosystem landscape with unique characteristics, both physically, chemically, and biodiversity. Anthropogenic activities in peatland use and disasters pose a threat to the preservation of the peatland ecosystem, which has impacts toward abiotic to the element of biodiversity (biotic). The purpose of this research is to model how the threat of the peatland ecosystem by using spatial data modeling. The method in this research using cloud-based GIS data analysis from Google earth engine, modeling distance parameter to variable modeling of interaction among landscapes on the peatland, and weight sum the value over raster-based spatial layer to determinate the thereat in the peatland ecosystem. The results of this study found zones where hot spots often occur. Modeling with euclidean distance to all modeling variables (except temperature) gives a clear effect on how the threats from each landscape interact with each other. We found that the threat of peatland damage in the high threat class dominates the plantation area reaching $30.9 \%$ of the total peatland area, whereas the forest landscape only has a high threat with a percentage of $1.9 \%$ and a low threat which the ecosystem is stable and natural reaching over $34.7 \%$. From this model, we succeeded in bringing up the idea to determine the priority area for policies where need to be done in handling the protection of peatland ecosystems, especially in plantations where the highest percentage of the ecosystem threat is in the high level with integrated peatland management.
\end{abstract}

Keywords: Peatland ecosystem, landscape, threat

DOI: $10.33541 /$ sp.v21i3.2259

Sociae Polites : Majalah IImiah Sosial Politik

Faculty of Social and Political Science, Universitas Kristen Indonesia

ISSN 1410-3745 print/ ISSN 2620-4975 online

Volume 21, Number 2 (Youth Peatland Conference)

Pages 196-211 


\section{Introduction}

\subsection{Background}

Peatland is a wetland ecosystem formed by the accumulation of organic matter on the forest floor from the ruins of vegetation above it over a long period of time (thousands of years). This accumulation occurs because the rate of decomposition is slow compared to the rate of accumulation of organic matter on the wet/inundated forest floor. Physically, peatlands are usually organosilica, or histosolic soils water-saturated or submerged all year long unless drained. Some experts define peat in different ways (Departemen Dalam Negri 2006). Peatland has unique physical and chemical characteristics and has a contribution to maintaining environmental stability when the peatland is in its natural state. Peat has become a problem that has become a source of various environmental problems when human interference disturbs the stability of the peatlands without proper handling (Agus and Subiks, 2008).

Peatlands are unique, complex ecosystems of global importance for biodiversity conservation at genetic, species, and ecosystem levels. There are many species found only or mainly in the peatlands. These species are adapted to the special acidic, nutrient-poor, and water-logged conditions of peatlands. Peatlands play a special role in maintaining biodiversity at the species and genetic level as a result of habitat isolation and at the ecosystem level as a result of their ability to self-organize and adapt to different physical conditions (Global Environmental Center, 2007). Peatland forest that is grows in an organic layer with a thickness of $\pm 50 \mathrm{~cm}$. This layer of organic matter consists of collisions of dead plants such as leaves, roots, twigs, and even complete tree trunks, which have accumulated over thousands of years. The peat layer is formed because plants that die under normal conditions are quickly decomposed by bacteria and other organisms, however, due to the anaerobic nature of the peat soil and its acidity (Susandi, 2015). Peatland ecosystems are very important in the hydrological system of a downstream area of a watershed because they are able to absorb water up to 13 times their weight. In addition, peat areas are also a very large store of carbon stocks, both above and below the ground (Agus dan Subiks, 2008). Peatlands have a very important role in human life and other living creatures that are above and around them. Peatlands do not only function as direct life support (for example, as a source of freshwater fish, a variety of habitats living things) but also have various ecological functions such as controlling floods and controlling the global climate (Departemen Dalam Negri 2006).

Many peatlands are still forest cover and provide habitat for various species of rare fauna and plants. More importantly, peatlands store large amounts of carbon (C). Peat also has a high water-holding capacity, so that it functions as a hydrological buffer for the surrounding area. Conversion of peatlands will disrupt all functions of the peatland ecosystem (Agus dan Subiks, 2008). Threats from land use and management to the peatland ecosystem have an impact on various elements in the ecosystem, including the availability of natural habitats and biodiversity (Global Environmental Center, 2007). The fires in peatlands that occur almost every year during the dry season have caused damage and disruption to the peat ecosystem at a very alarming level (Kementrian Lingkungan Hidup dan Kehutanan, 2015). Peatland areas will be difficult to recover from if they are damaged. (Departemen Dalam Negri, 2006). Damage to the peat ecosystem has a major impact on the local environment (in situ) and the surrounding environment (ex-situ). The occurrence of flooding in the downstream watershed is one of the impacts of the peat ecosystem destruction. Deforestation of forests and use of peatlands for agricultural systems that require deep drainage $(>30 \mathrm{~cm})$ and burning or fires 
cause very high CO2 emissions (Agus dan Subiks, 2008). They are vulnerable to changes resulting from direct human intervention, changes in their water in the catchment, and climate change, which may lead to loss of habitats, species, and associated ecosystem services. The biodiversity values of peatlands demand special consideration in conservation strategies and land use planning (Global Environmental Center, 2007).

The utilization of peatlands in Indonesia is very rapid, especially land expansion for the needs of oil palm plantations, industrial plantations, where the development of peatlands always has to deal with environmental issues (Sabiham and Sukarman, 2012, Agus, 2013). Management that causes fragmentation inhibits ecosystem networks (Hidayat, 2019). One of the many environmental issues of peat is fire. Peatland fires have different characteristics from fires in mineral soil areas. In peatland fires, fire is not only on the surface where it is relatively easy to extinguish, but the spread of fire on peatlands also occurs below the surface (ground fire), where the detection and extinguishing process becomes very difficult because it must be done from inside the peat alone and from above (Dariah and Maswar, 2014). The international symposium on tropical wetlands entitled "Peatlands for People," which was held in Jakarta on 22-23 August 2001, produced a recommendation called the Jakarta Statement on The Importance of Tropical Peatlands. This statement urges all parties to pay attention to greater efforts to conserve peatland biodiversity and carbon stocks. The Riau Declaration was delivered after the implementation of an international workshop entitled "Workshop on Vulnerability of Carbon pools in Tropical Peatlands" on 23-26 January 2006 in Pekanbaru. The Riau Declaration, among others, provides recommendations on the need to strengthen policies and institutions for peatland management and explicitly supports them (Departemen Dalam Negri 2006).

The real problem that occurs in peatland areas and a lot of encouragement in congresses and seminars has emphasized the importance of efforts to protect peatlands as the basis for strengthening the reasons for this research. The purpose of this study was to analyze and conduct spatial modeling of the threat level to the sustainability of the peatland ecosystem. Therefore, the basis of this research limitation is only to do threat modeling with spatial data, not using survey data. In this study, the threat of the peat ecosystem damage. In general, it represents the threats caused by land exploitation, cultivation activities in the management of agricultural land, and plantations to these ecosystems and their environment. This model will give an indication of the threat of ecosystem damage when many variables affect and influence the same location. In this study, to measure threats from land use on peatlands and peatland forests ecosystem, using a Geographical Information System modeling, where all this data represent a space that affects the location and area around the location

\section{Research Method}

\subsection{Data}

To solve the problem in modeling, we use some spatial data from the authorized institution as the data guardian and from valid sources as data to be analyzed for this modeling. The derived from related institutions such as from Geospatial Information Agency or Ministry of Forestry and Environment, the data can be derived high or moderate resolution imagery such as sentinel 2A from http://earthexplorer.usgs.gov for classifying the land cover. MODIS (Moderate Resolution Imaging Spectroradiometer) imagery we used derived from the processing in Google earth engine, peatland map from Ministry of Agriculture Indonesia, and 
other additional data such as from related agency and OSM. In creating this model, all vector data are converted to be raster data.

\subsection{Modeling Variable}

In spatial modeling of threats from land use to natural peatland ecosystems that will impact habitat and biodiversity, we use several very important indicators. We conducted a literature study to obtain justification that this variable is important for spatial modeling. These variables have a very significant role in causing damage to the ecosystem, which results in a loss of biodiversity.

Table 1. Variable Modeling

\begin{tabular}{cc} 
Variable & Reference \\
\hline Agricultural & Perrings, (2015) Gutharie., et.al (2018) \\
Plantation & $\begin{array}{c}\text { Saavedra and Simonetti (2005) (Barun, } \\
\text { 2017) Petrenko (2016) }\end{array}$ \\
Fire Forest & $\begin{array}{c}\text { Secretariat of the Convention on } \\
\text { Rivers }\end{array}$ \\
Road and & (2017) \\
Infrastructure & (2001). Syaufina \\
Settlement & (Li Yunzhao., et.al, 2014) (Bennett, \\
2017). \\
Elmquist T., et al. (2013)
\end{tabular}

The variables we choose in this study are those we can get from satellite data, and geospatial data, or data that can be represented spatially. We limit the use of non-spatial variables.

\subsection{Data Analysis}

\subsubsection{Preprocessing}

In the processing data, we carried out here by designing all the specific data which become the assessment variable for determining the threat zone of the peatland ecosystem damage. In a general aspect, this process is divided into two, the first extracting information from satellite images to obtain hotspot information for the past ten years, and second, calculating the effect of each parameter on the surrounding environment using the distance.

a) Collecting Hotspot Zone

Hotspot data collection is done by using Google Earth Engine. In this stage, mark the Tera Modis satellite data to obtain land surface temperature information, using several algorithms. The raster counts from the results of hotspot data over a period of 10 years to determine which zone always has the highest hotspot. 


$$
\mathrm{T}=(\operatorname{LST} 1+\operatorname{LST} 2+\ldots \ldots \ldots . .+\mathrm{LST} 10)
$$

b) Land Cover

$\mathrm{T}=$ total hotspot temperature

LST $=$ Land surface temperature

Land cover classes are derived from the Geospatial Information Agency or Ministry of Forestry and Environment. Then the data can be revalidated through the editing process. To obtain the information about the land cover can also by interpreting the Imagery by digitizing and editing process. We need to obtain a land cover map as the basic Map for developing into the model variable. Digitation done for gaining the proper data is not pixel-based and without doing ground survey because the interpretation not using computer classification by statistic probabilities. We corrected with the higher resolution imagery using Google Earth.

c) Euclidean Distance

The distance is determined by selecting and separating the land cover map into each indicator using the euclidean distance tool. These variables are measured by the influence of distance, these subject; namely, Plantation, Agriculture, Settlements, Roads, and Rivers. We chose the data design in the form of distance based on the results of literature studies, in which the main location will have the highest threat, and the influence on the surrounding environment will gradually decrease with the distance traveled.

$$
\operatorname{Inv}=(\max \mathrm{D}+1)-\mathrm{D}
$$

where:

$$
\begin{aligned}
& \text { Inv }=\text { Inversed Distance } \\
& \text { Max }=\text { Maximum raster value of Euclidean distane } \\
& \mathrm{D} \quad=\text { Raster euclidean distance }
\end{aligned}
$$

\subsubsection{Processing of The Model}

At this modeling process, the data analysis was carried out in the raster overlay model of all variables to determine the dominant sport in the threat zoning of the peatland ecosystem. Modeling distance with euclidean distance to all modeling variables will give effect to around area. It will suspect the threats from each landscape interacts with each other.

$$
\mathrm{A}=\left(\mathrm{T}+\mathrm{I}_{\text {Settlement }}+\mathrm{I}_{\text {Road }}+\mathrm{I}_{\text {Agricultural }}+\text { IPlantation }-\mathrm{I}_{\text {Rivers }}\right)
$$

Where:
A $=$ Index of peatland ecosystem threat
$\mathrm{T}=$ Total temperature (hotspot zone)
I = Inverse of Euclidean distance of each variable 
After we get the result from this model, we use statistic correlation assessment to measure how the values among these variables interact to this model, by purposive technic to identification how the contribution among variables to this model. The correlation values are calculated to be a percentage of presenting the contribution of each variable.

Figure 1. Illustration of the model process

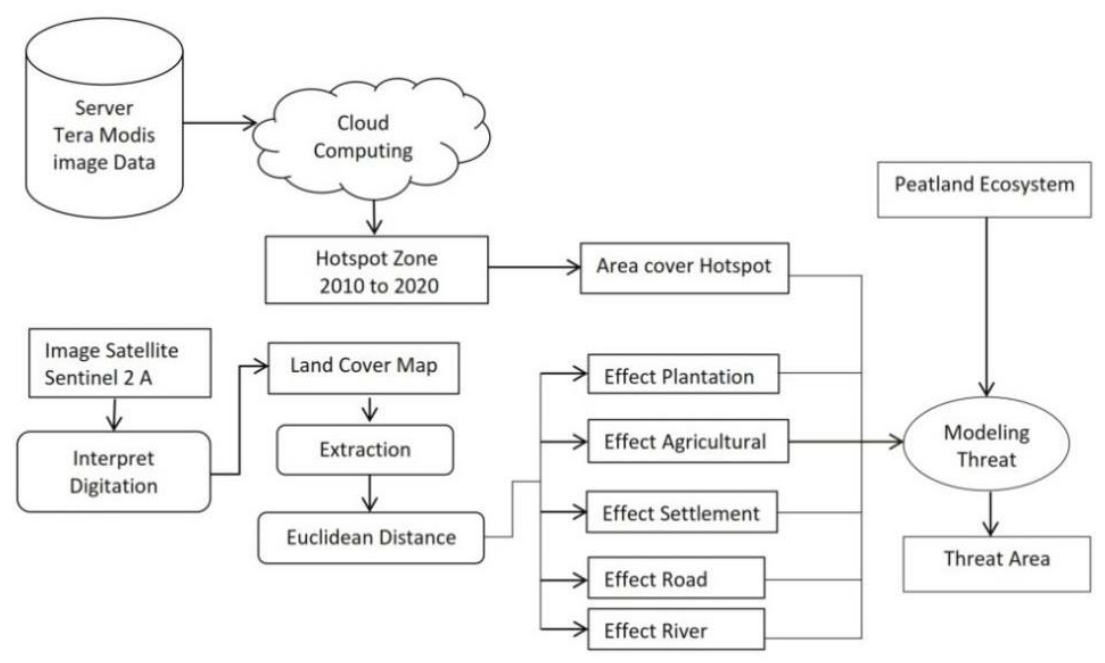

\section{Results and Discussions}

The result of spatial modeling has succeeded in presenting the effects of spatial interactions of un-natural landscape ecosystems that are driving threats to the damage of the peatland ecosystem to surrounding landscapes. The first is the influencing variable of plantation and agriculture landscape to the peatland ecosystem. This variable has presented various influences from agricultural and plantation by the land management activities, where the human activities in the area give impact such as damage habitats and destroy the population of peatland biodiversity. Invasive species are cultivated on peatlands, such as oil palm, which inhibits the supply of food for biota and reduces the carbon stock of peatlands. Not only that, the land clearing activity for investing plantations does not only change the cycle of water reserves on the site of peatlands. However, it also affects the environment around the plantation area above the peatland area. Nevertheless, Hotspots and road networks make a clear contribution as an ecosystem modeling variable. This can be observed in the variable Map above, where the area adjacent to the road has a significant threat effect, while the forest interior far from the road receives a weak effect. This total hotspot is a representation of hotspot records in the past ten years. We find that the distribution of these hotspots is dominant in the plantation landscape. We suspect that the dynamic conditions of this hotspot it is a representation of activities in plantation such as land management, bare land after land clearing, or burning. 
Figure 2. Variables used in the model

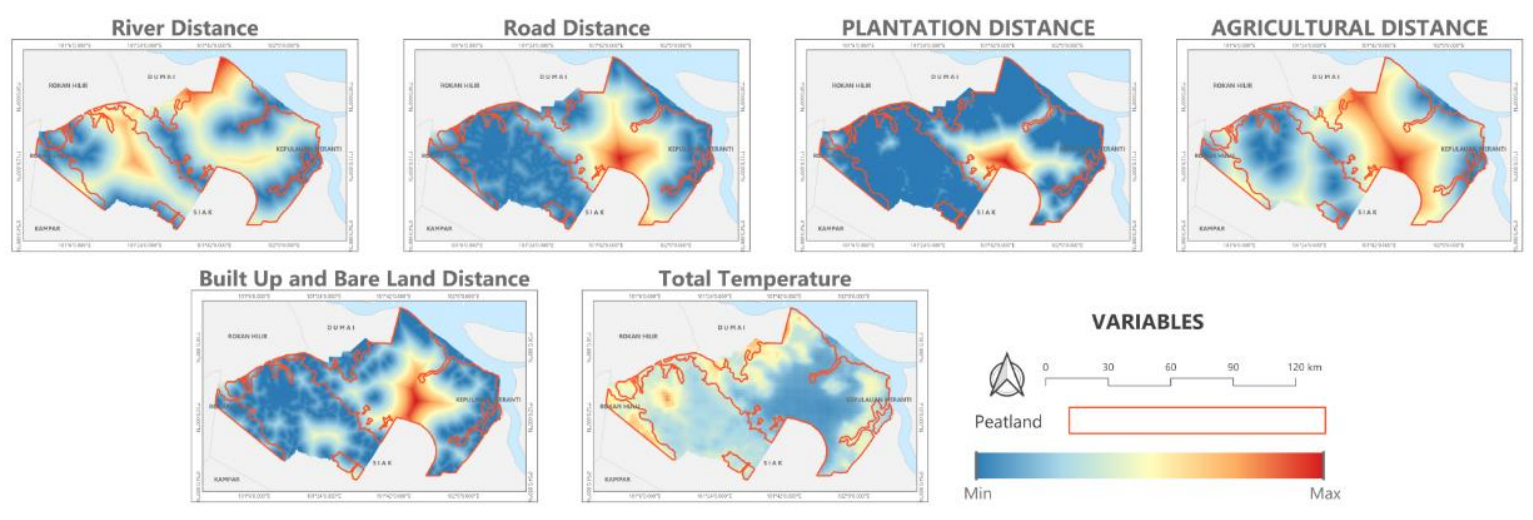

The last is settlements have a quite significant impact on the surrounding of the microenvironment. We can see the distribution of settlement spots, which has a fairly clear effect on the surrounding. Uncontrolled settlements pose to be a threat to the sustainability of the ecosystem by building infrastructure that destroys ecosystems or waste, and household chemical waste, as well as activities that threaten the sustainability of the ecosystem. These variables are then overlaid to obtain the threat index of damage of the peatland ecosystem in our research location.

Table 2. Variable Contribution

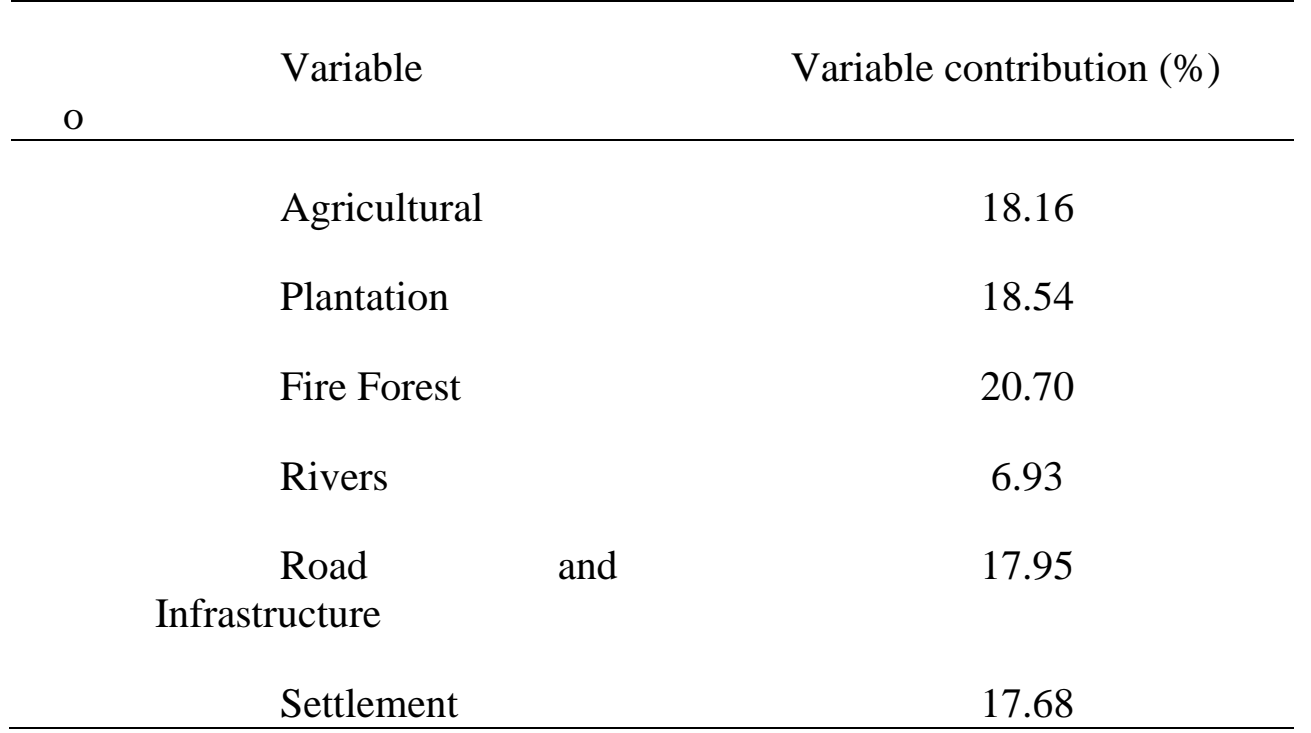

We had extracted the results from this modeling into the contribution of variables. We use this to see the types of variables in the model that greatly influence this spatial model. From the results of our calculation, we find that variable of plantations contributes at numbers of $(18.54 \%)$, agricultural land contributes to the model in numbers $(18.16 \%)$, not only that, the fire hotspots variable for the past ten years give a contribution at the number of $(20.70 \%)$. Furthermore, the contribution of road and settlement variables reached $(17.68 \%)$ and $(17.68 \%)$. We know that the variable hotspot exerts a very large influence in this model, so it becomes the basis for a very important consideration. While the variable of plantation and agricultural is the variable with the second contribution value, we also need to pay attention to these variables as the indicators that drive threats to the peatland ecosystem. Although other 
variables do not contribute significantly, their influence must be considered because they still have an impact on the physical and ecological conditions of the peatlands.

The Map below represents the combination of all variables related to their impact on the peatland ecosystem. This Map indicates the peatland ecosystem, which less threatened of ecosystem damage (blue) into the critically threatened of ecosystem damage (red). This Map shows the distribution of the threat on peatland. We can observe this study area has dominated by the high threat; however, the lowest threat only in the center of the forest area.

Figure 3. The Map demonstrates the distribution of peatland ecosystem threat in the mainland of Bengkalis

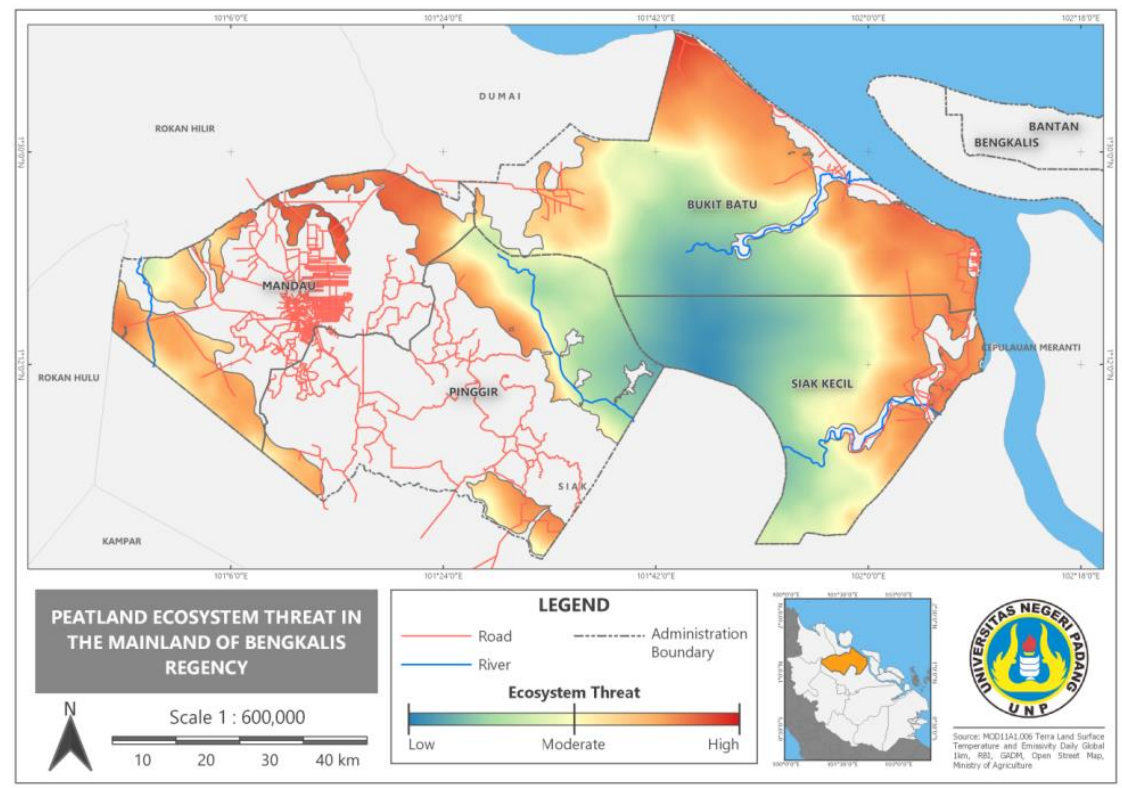

This model of ecosystem threat in the dominant ecosystems in the peatland of Bengkalis Regency is the supporting data that this model works in particular ecosystems. As informed from the previous part, one of the essential threats in the peatland of Bengkalis Regency is a plantation. This is also used as our variable in this modeling. This model shows the ecosystem threat in the peatland plantation are mostly high, also considering in this area tends to occur, land clearing and even bushfires which absolutely damage the ecosystem and biodiversity within this area. It is inversely compared with the forest, which is also the dominant ecosystem in our study area. Forest takes a role as the source of biodiversity richness and the highest habitat potential for various species. The model indicates the forest as the area which has very less threat, which prominently represented by green and blue accumulating in this area

The distribution of peatlands in Bengkalis district varies; Bukit Batu Sub-district has an area at the number of 151.935 hectares, while the Sub-district of Siak Kecil has an area number of 111.836 hectares, then the Sub-district of Pinggir is in the area at a number of 60.825 hectares, and the last is the Mandau sub-district with an area of 47.088 hectares. The percentage of peatland area has also been calculated based on the threat of damage criteria. This grouping is separated based on the administrative area of the sub-district to make it easier to understand the distribution by region 
Figure 4. The threat of peatland ecosystem divided by district

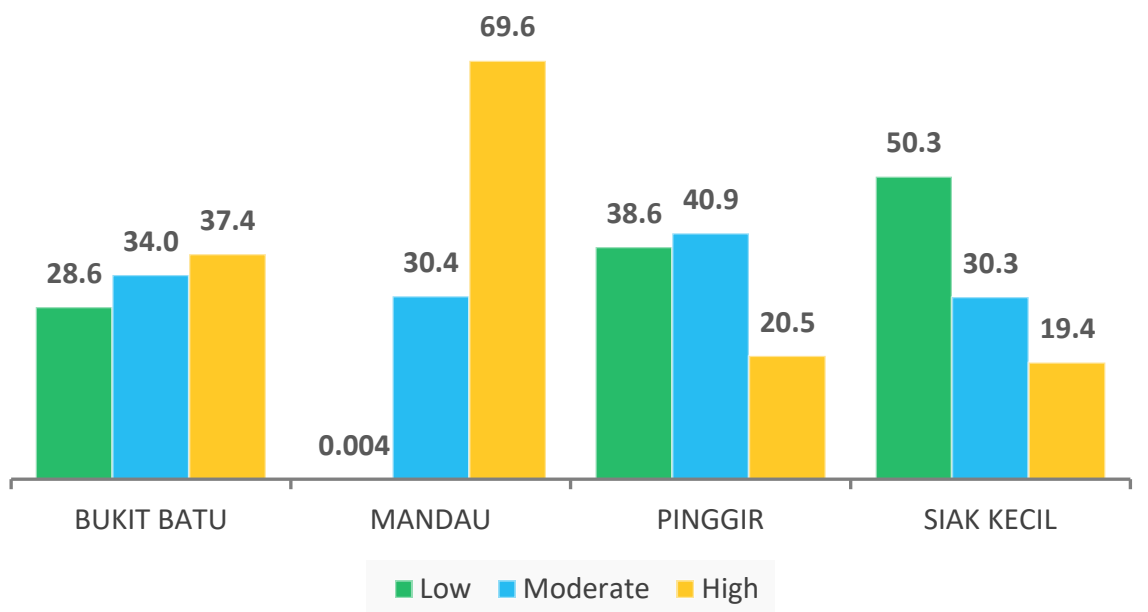

The figure represents how the distribution of ecosystem threats is disaggregated by the administration in percentage terms based on the total area of peatland. While the blue chart represents the percentage of peatland area in one administration, it is clear that Siak Kecil and Bukit Batu sub-districts have peatlands that are more than $85 \%$ of the administrative area. Meanwhile, Mandau and Pinggir only have peatlands of approximately $30 \%$. Overall, medium-class ecosystem threats are dominant in peatland areas. This informs an indication of the influence of many land management activities and environmental disasters. This can continue to be a threat to the ecosystems in serious damage. Nevertheless, The greatest threat to the peatland ecosystem is in the Bukit Batu sub-district. This is also related to the area of dominant peatland at the number of $37.4 \%$ (moderate threat).

Figure 5. Peatland ecosystem threat in the plantation (left) and forest(right) in threat in the mainland of Bengkalis Regencv, Riau Province.

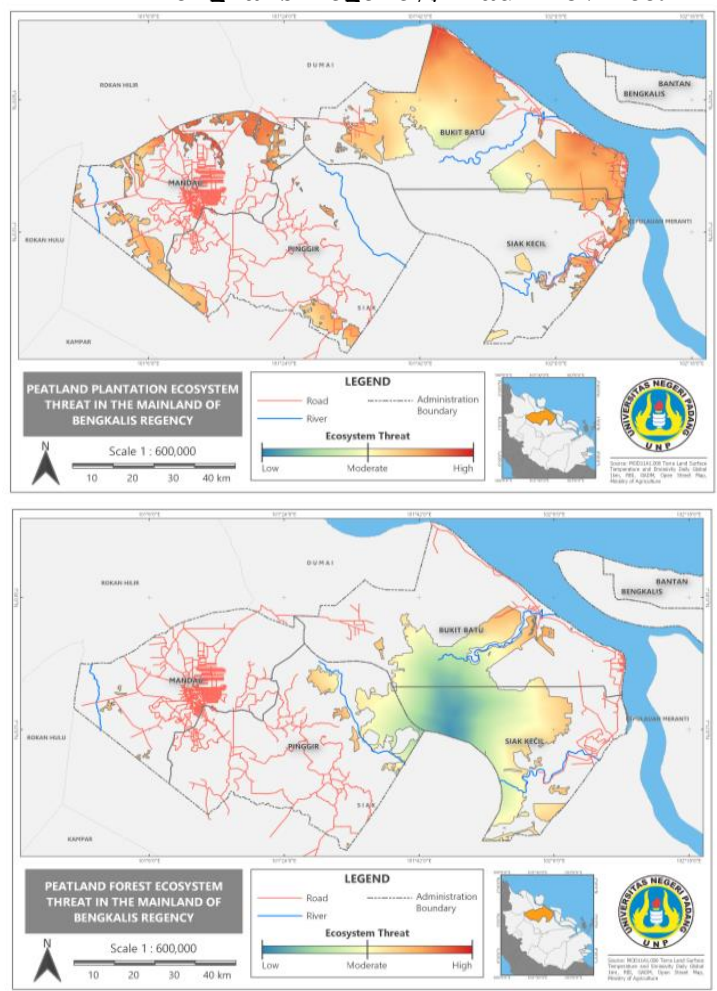


The maps reveal the threat of damage to the peat ecosystem on plantation land and forest, and it is clear that plantation areas have a large high ecosystem threat that is spread throughout the region. This high threat mainly occurs in plantation areas that are close to other variables such as agriculture, road infrastructure, and settlements. The area of peatland in each sub-district in Mandau is $47063.42 \mathrm{Ha}$, Pingggir is $60798.19 \mathrm{Ha}$, Bukit Batu is 151842.3 Ha, and Siak Kecil is $111789.51 \mathrm{Ha}$. We found that there are differences in dominant threats to the peatland ecosystem in each sub-district influenced by variables that have an effect that results in a high or low threat of damage to the peatland ecosystem.

The threat of peatland ecosystem damage is then grouped into several classes of the typical landscape. This aims to make it easier to understand how the threat distribution on the area based on land cover categories. From the chart below, it is generally clear that the natural landscape (peatland forest) is dominated by a low threat. Meanwhile, plantations are dominated by the high threat category. This indicates that anthropogenic activities have a major influence on the landscape.

Figure 6. The threat of the peatland ecosystem is divided into three dominant ecosystems.

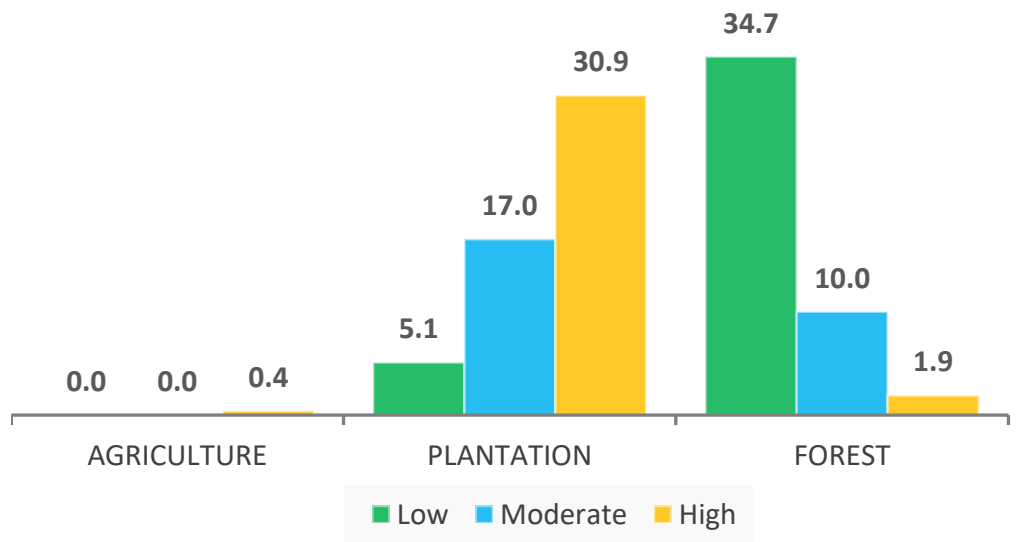

The chart illustrates the distribution of ecosystem threats based on each peatland landscape with land cover conditions, namely natural forest, plantation, and agricultural. The percentage calculation above is based on the landscape area and the area of the peatland ecosystem. In general, the most dominant landscape is a plantation, then forest, and the smallest is agricultural. For starters, plantation landscape has the highest threat with a percentage of $30.9 \%$, while forest landscapes only have a high threat at $1.9 \%$, then moderate threat in plantation landscapes is at $17.0 \%$, and this low threat is $5.1 \%$ spread across the forest border areas. Forests conversely have the highest percentage at the low threat that is $34.7 \%$ and followed by a moderate threat of $10.0 \%$.

This peatland ecosystem is unique and has special wealth, both physically (abiotic) and elements of biodiversity (biotic). This model has succeeded in proving that the threat to the peatland ecosystem with the utilization of plantation is a big threat. because basically the approach in this research is carried out with a spatial approach which represents the various activities that occur on plantation land, both management, water management, land clearing, to various activities that lead to complex ecosystems and loss of peatland biodiversity. the threat of activities on the peatlands that eliminate natural ecosystems in the developed area not only lead to damage to the ecosystem but also spread to other problems. (Barun, 2017) The plantation is a real challenge and threat to the ecosystem and biodiversity. This land 
expansion activity is a challenge for the preservation of the peatland ecosystem (Hanif et al. 2017. 2019) where a pure circle of the ecosystem and many native species are less frequent within plantations than within native forests, decline species population and many incident conflicts between animal and human because of the development of plantation area on the peatland ecosystem in Riau (Saavedra and Simonetti, 2005, Uryu, 2008).

\section{Figure 7. Spatial Interaction Among The Variables}

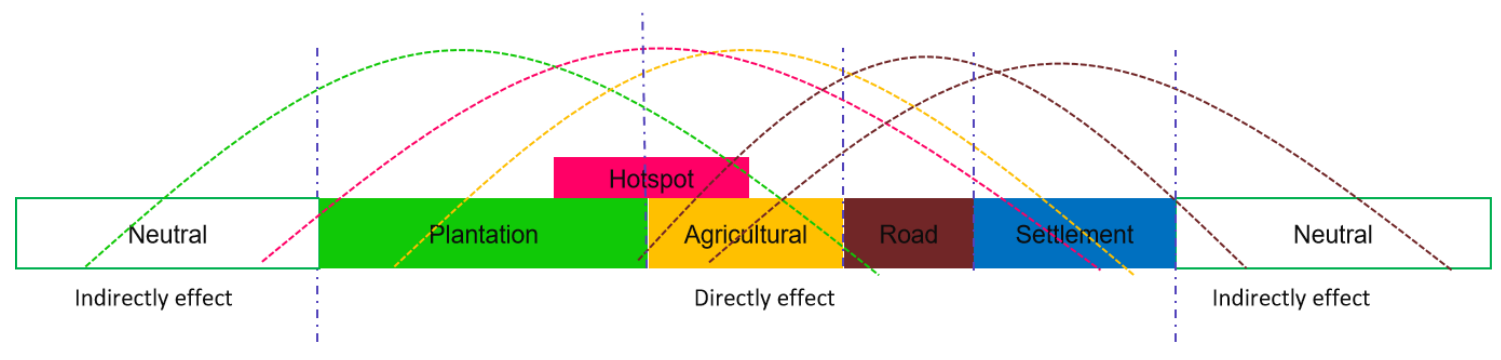

The figure above reveals how the variables influence each other. The straight lines bound the major effect on each variable. The effect of interaction among the variables represented by the curves from each variable. The curve will rise higher in the area of a variable, which reveals the effect of a variable increase if getting closer to the source itself, and the curve will gradually decline if it is farther away from the area of a variable, which reveals the effect of a variable decrease and mixed with other varieties. The hotspot position is on the plantation and agricultural means the occurrence of hotspot tendency because of the impact of land clearing and burning.

This spatial approach is a representation of all agricultural cultivation activities in general. It covers anthropogenic activities starting from initial processes such as developing land for agriculture to investing in cultivating and protecting cultivated vegetation using insecticides and other activities. All activities in the management of agricultural areas can threaten the environment. This activity produces residual substances that are toxic to the environment and water resources in the peatlands. Not only that, improper peatland water management activities lead to an imbalance in the peatland water balance. In this Bengkalis area, agricultural land is scattered around the plantation area; of course, this land also gets the impact of the activities of the plantations that surround it so that the threat is more complex. Perrings (2015, Gutharie. et al., 2018, and Hidayat 2020) There is a strong positive correlation between the extensive growth of agriculture and threats. Land conversion has a direct implication of this is that among low-income countries. Tropical peatlands deserve special mention, as drainage of these peatlands management makes them particularly vulnerable to fire, especially ground fires, which produce noxious smoke. Fires penetrated into the dried-out surface of peat to a depth of up to 1.5 meters, and between 750 million and one billion tonnes of carbon were released into the atmosphere from Indonesia alone (Asian Development Bank, 1999; SCBD, 2001, and Syaufina, 2017).

The Anthropogenic activities in the management of plantation and agricultural land, in general, are also carried out with a hotspot model approach; this indicates the occurrence of chronic hotspots at the location. The fact is that peatland forest fires destroy the ecosystems not only on the surface but fire can spread in the peat soils so that the loss of biodiversity and the purity of ecosystems in a location is represented. According to IUCN/WWF, The fire forest and wildlife fire be a real threat to the peatland ecosystem. The negative impacts 
associated with large scale uncontrolled forest fires have increased worldwide over the past two decades (IUCN/WWF, 2000). The hotspots that we have collected representing over the past ten years have succeeded in providing an indication of areas of the peat ecosystem that often occurs hot temperatures. These hotspots provide a fairly clear impact on the threat zones of the peatland ecosystem. It cannot be denied that when a hotspot occurs, which is an indication that the fire on the surface of the peatlands will destroy the constituent elements of the peatland to the ecosystem that lies below the surface of the peatland in Bengkalis Regency - following (Asian Development Bank, 1999; SCBD, 2001, and Syaufina, 2017) In the tropical forest ecosystems. The effect of fire in the forest cause plants and fauna highly threatened to death. Indirect effects of fires are far-reaching and longer-term and include stress, loss of habitat, territories, shelter, and food.

The development of road network infrastructure and settlements certainly poses a real threat to the peatland ecosystem. This is part of land exploitation and breaks the ecosystem connectivity chain due to the stretching of the road network as an ecosystem barrier. Li Yunzhao. et al., (2014) the natural ecosystem, the biodiversity of plant communities are deeply affected by roads (Bennett, 2017). Nevertheless, The development of the road network is moving toward larger scales. However, it also became evident while compiling this special issue that much higher order, e.g., population, community, ecosystem, or landscape level, effects remain unquantified (Ree der van Rodney, et al. 2011).

When viewed from the administrative area, which has the largest area of peatland, the first priority is Bukit Batu with a high threat of $37.4 \%$ conditions, and the second-largest peat ecosystem area is Siak Kecil District, this area has a high threat of ecosystem damage, only $19.4 \%$ - and dominated by low threats at $50.3 \%$. From the condition of its spatial distribution, we understand that the condition of the land cover of this plantation is mostly in the Bukit Batu sub-district, and the condition of the vast peatland ecosystem, with these two main points, this sub-district is the main priority target in the peatland protection. We are aware that in the direction of the plantation, it has indeed had a big impact on environmental damagethe areas where the hotspots recorded in the past ten years need special supervision and management. As seen from the condition of the land cover, there are still many peatland forest ecosystems. This is able to encourage anthropogenic activities in the surrounding area. We believe that the policy that needs to be done for this area is managed so that no further damage to the natural ecosystem occurs, and optimizing existing conditions of plantations and agriculture. Not only that, it is necessary to carry out integrated peatland management that is truly oriented towards protecting the peatland ecosystem.

\section{Conclusions and Recommendations}

The spatial modeling integrated cloud data and spatial analysis for identifying the threat of damage to peatland ecosystem using GIS model that has been applied are able to represent the distribution of peatland threats due to the existing conditions of land use on peatland. It has successfully assessed high, medium, and low threat areas. The distribution of peatlands in an administrative area will not be linear with the threats posed by neighboring areas. In the future management of peatlands, it is necessary to carry out an integrated plan and management with neighboring administrative areas in order to be able to reduce the effects of threats as a mitigation effort to protect peatlands. Plantation variables, agriculturerelated hotspots are the main points that must be considered for the design of activities. The indication of this model is a form of the initial approach as a priority for policymakers. We 
recommend that more specific management is supposed to be integrated with the regional planning map (RTRW) and the management direction of the special area. 


\section{BIBLIOGRAPHY}

\section{Book}

Agus, F. dan I.G. M. Subiksa. 2008. Lahan Gambut: Potensi untuk Pertanian dan Aspek Lingkungan. Balai Penelitian Tanah dan World Agroforestry Centre (ICRAF), Bogor, Indonesia.

Departmenet Dalam Negeri. 2006. Strategi Dan Rencana Tindak Nasional Pengelolaan Lahan Gambut Berkelanjutan. Jakarta. Kelompok Kerja Pengelolaan Lahan Gambut Nasional.

Dariah And Maswar. 2014. Lahan Gambut Indonesia Pembentukan, Karakteristik, Dan Potensi Mendukung Ketahanan Pangan. Badan Penelitian Dan Pengembangan Pertanian Kementerian Pertanian.

Elmqvist T., et al. 2013. Urbanization, Biodiversity and Ecosystem Services: Challenges and Opportunities. ISBN 978-94-007-7087-4 ISBN 978-94-007-7088-1 (eBook) DOI 10.1007/978-94-007-7088-1 Springer Dordrecht Heidelberg New York London.

Kementrian Lingkungan Hidup dan Kehutanan 2015. Pedeoman Pemulihan Lahan Gambut. Jakarta, Indonesia.

\section{Journal}

Agus, F., A. Dariah, dan A. Jamil. 2013a. Kontroversi pengembangan perkebunan sawit pada lahan gambut. Hlm. 454-473. Dalam Haryono et al. (Eds.). Politik Pengembangan Pertanian Menghadapi Perubahan Iklim. Badan Penelitian dan Pengembangan Pertanian. Kementrian Pertanian. IAARD, Jakarta.

Braun., et al. 2017. Assessing the impact of plantation forestry on plant biodiversity a comparison of sites in Central Chile and Chilean Patagonia. Journal of Global $\begin{array}{lllll}\text { Ecology and } & \text { Conservation } & 10 & \text { (2017) }\end{array}$ http://dx.doi.org/10.1016/j.gecco.2017.03.006

Bennett. 2017. Effects of Road Density and Pattern on the Conservation of Species and Biodiversity. Curr Landscape Ecol Rep (2017) 2:1-11. DOI 10.1007/s40823-0170020-6

Hanif M and Nofrizal A Y (2017) Investigation Natural Forest Ecosystem Use High Resolution and Lidar Data. Journal Environment and Earth Science IIESTE. Vol 9.

Hanif M et al. (2019) Multi-Spectral Satellite Data to Investigate Land Expansion and Related Micro Climate Change as Threats to the Environment. Journal. IOP Conference Series: Earth Environ. DOI: 10.1088/1755-1315/303/1/012030. 
Hidayat Riski Atthoriq, (2019) Spatial Analysis Of Urban Ecosystem Networks for Biodiversity Conservation In Padang City. Conference Paper. BIOETI-IV-IWS-V. Wildlife conservation. Universitas Andalas.

Hidayat Rizki Atthoriq et al. (2020) Modeling of Conservation Priority Zone for the Helmeted Hornbill (Rhinoplax Vigil) In Silokek Geopark Area, West Sumatra. DOI 10.20944/preprints202009.0676.v1.

Li Yunzhao., et al. 2014. Ecological Effects of Roads on the Plant Diversity of Coastal Wetland in the Yellow River Delta. Scientific World Journal Volume 2014, Article ID 952051, 8 pages http://dx.doi.org/10.1155/2014/952051

Ree der van Rodney, et al. (2011) Effects of Roads and Traffic on Wildlife Populations and Landscape Function: Road Ecology is Moving toward Larger Scales. Journal of the Resilience Alliance. http://www.ecologyandsociety.org/vol16/iss1/art48/.

Saavedra, B., Simonetti, J.A., 2005. Small mammals of Maulino forest remnants, a vanishing ecosystem of south-central Chile. Mammalia 69 (3-4), 337-348.

Sabiham, S. dan Sukarman. 2012. Pengelolaan lahan gambut untuk pengembangan kelapa sawit. Dalam Husen et al. (Eds.). Prosiding Seminar Nasional Pengelolaan Lahan Gambut Berkelanjutan. HLm. 1-17. Badan Litbang Pertanian. Kementrian. Pertanian. Bogor, 4 Mei 2012

Susandi, et.al. 2015. Analisis Sifat Fisika Tanah Gambut Pada Hutan Gambut Di Kecamatan Tambang Kabupaten Kampar Provinsi Riau. Jurnal Agroteknologi, Vol. 5 No. 2, Februari 2015 : 23-28 


\section{Detail Result of This Model}

\begin{tabular}{|c|c|c|c|c|c|c|c|c|c|c|c|c|c|}
\hline \multirow{3}{*}{ Sub-District } & \multirow{3}{*}{$\begin{array}{c}\text { The Peatland } \\
\text { Area } \\
\text { (Hectare) }\end{array}$} & \multirow{2}{*}{\multicolumn{3}{|c|}{$\begin{array}{c}\text { The Threat of Damage of } \\
\text { Peatland divided by } \\
\text { Administration }\end{array}$}} & \multicolumn{9}{|c|}{ The Threat of Damage of Peatland divided by Landscape Ecosystem } \\
\hline & & & & & \multicolumn{3}{|c|}{ Forest } & \multicolumn{3}{|c|}{ Plantation } & \multicolumn{3}{|c|}{ Agricultural } \\
\hline & & Low & Medium & High & Low & Medium & High & Low & Medium & High & Low & Medium & High \\
\hline Siak Kecil & 111836 & 50.3 & 30.3 & 19.4 & 77.3 & 22.2 & 0.5 & 3.3 & 22.8 & 73.9 & 0 & 4.6 & 95.4 \\
\hline Bukit Batu & 151935 & 28.6 & 34 & 37.4 & 68.1 & 19.5 & 68.1 & 19.5 & 48.4 & 32.1 & 0 & 5.5 & 94.5 \\
\hline Mandau & 47088 & 0.04 & 30.4 & 69.6 & 0 & 29.7 & 70.3 & 0 & 33.6 & 66.4 & 0 & 56.4 & 43.6 \\
\hline Pinggir & 60825 & 38.8 & 40.9 & 20.5 & 70.1 & 26.4 & 3.5 & 0 & 41.2 & 58.8 & 0 & 0 & 0 \\
\hline
\end{tabular}

